\title{
A FAMILY ILLUSTRATING THE DOUBLE INHERITANCE OF THE SICKLE CELL TRAIT AND OF MEDITERRANEAN ANAEMIA
}

BY

\author{
J. G. HUMBLE, IAN ANDERSON, AND J. C. WHITE \\ From the Departments of Haematology and Paediatrics, Westminster Hospital, London, and the Department of \\ Pathology (Haematology), Postgraduate Medical School of London \\ AND \\ TRISTRAM FREEMAN \\ From the Department of Puthology, St. Mary's Hospital. London
}

(RECEIVED FOR PUBLICATION APRIL 10, 1954)

Application of the precise methods of physical chemistry to medical problems frequently provides an exact explanation of hitherto imperfectly understood phenomena. This is well illustrated by the recent advances made in the understanding of sickle cell anaemia and the sickle cell trait. In 1949, Pauling, Itano, Si-ger, and Wells demonstrated that the carbon monoxide derivative of the haemoglobin derived from the red cells of sickle cell anaemia possessed a different mobility from normal haemoglobin. They showed that the red cells of sickle cell anaemia contained almost entirely this " sickle" haemoglobin, whilst the red cells of sickle trait carriers contained about $50 \%$ sickle haemoglobin and $50 \%$ normal haemoglobin. In 1950, Perutz and Mitchison demonstrated that reduced sickle haemoglobin was extremely insoluble and the crystals formed were similar to red cells that had undergone " sickling." Thus sickle cell haemoglobin joined normal haemoglobin and foetal haemoglobin as a separate variety of human haemoglobin. In 1951 (a and b) Singer, Chernoff, and Singer demonstrated up to $24 \%$ foetal-type haemoglobin in sickle cell anaemia but did not find any in 60 sickle trait carriers. Foetal haemoglobin was also found in other forms of inherited haemolytic anaemias, especially in the severe forms of Mediterranean anaemia. This latter finding was confirmed by Liquori (1951) who found between 40 and $60 \%$ of foetal haemoglobin in seven cases of the homozygous form of Mediterranean anaemia (Cooley's anaemia). In sickle trait carriers 24 to $45 \%$ of the haemoglobin is usually found as sickle haemoglobin (Wells and Itano, 1951). These authors mention anomalous sickle cell anaemia cases with 80 to $95 \%$ sickle haemoglobin and 5 to $20 \%$ normal haemoglobin.
Singer and Fisher (1953) found a family of sickle trait carriers with so little sickle haemoglobin $(5 \%)$ that the red cells would not sickle. Two other separate haemoglobins have also been discovered, haemoglobin III or C (Kaplan, Zuelzer, and Neel, 1951) and haemoglobin D (Itano, 1951). There are thus five varieties of human haemoglobin: normal adult or A, foetal or F, sickle haemoglobin $S$, and haemoglobins $C$ and D (National Institutes of Health, 1953) *

By combining the results obtained by electrophoresis and by quantitative alkali denaturation (Singer) the red cells of sickle cell anaemia are usually found to contain sickle haemoglobin 76 to $100 \%$ and foetal haemoglobin 2 to $23 \%$ only. The red cells of the sickle carrier contain sickle haemoglobin 5 to $45 \%$ and 95 to $55 \%$ normal A haemoglobin. The red cells of the severe (homozygous) form of Mediterranean anaemia contain normal adult haemoglobin with from 5 to $60 \%$ foetal haemoglobin. The mild (heterozygous) form of Mediterranean anaemia usually contains only adult haemoglobin in their red cells. Intermarriage between Mediterranean anaemia and sickle cell families has been described in Italy (Silvestroni and Bianco, 1952), in America (Powell, Rodarte, and Neel, 1950; Sturgeon, Itano, and Valentine, 1952; Neel, Itano, and Lawrence, 1953), and in Greece (Caminopetros, 1952). The inheritor of both traits suffers as a rule from haemolytic disease of moderate severity. The following family appears to be the first described in England. It was discovered by the coincidental illness of one of its members.

\footnotetext{
* Two further haemoglobins have been recently described, haemoglobin E (Itano, H., Bergren, W. R., and Sturgeon, P., 1954, J. Amer. chem. Soc., 76, 2278), and haemoglobin G (Edington, G. M., and Lenmann, H., 1954, Lancet, 2, 173).
} 


\section{Case Report}

Mary H., aged 12 years 5 months, was sent to hospital on February 20, 1951, at 1 a.m. with a two-day history of sore throat, abdominal pains, and nausea. She was a thin, intelligent child, her facies definitely Caucasian (Fig. 1). The tonsils were red and the fauces injected, temperature $100^{\circ} \mathrm{F}$. $\left(38.4^{\circ} \mathrm{C}\right.$.), pulse 120 per minute. There was tenderness and " guarding " in the right lower quadrant of the abdomen and she was markedly tender on the right side per rectum. The liver and spleen were not palpable. A white cell count was 14,500 per c.mm. (neutrophil polymorphs $82 \%, 11,890$, lymphocytes $12 \%$, 1,740 , monocytes $6 \%, 870$. A diagnosis of acute appendicitis was made and appendicectomy was performed at $3 \mathrm{a} . \mathrm{m}$. The appendix was thickened, tortuous, reddened, and inflamed. On the morning of February 22 the patient was definitely jaundiced. There was no bilirubin in the urine. The liver and spleen were palnable two fingerbreadths below the costal margin. The blood was examined and showed haemoglobin 7.55 g./ 100 ml., red blood cells $2,700,000$ c.mm., packed cell volume $26 \%$, M.C.V. $95 \mu^{3}$, M.C.H. $27.5 \mu \mu \mathrm{g}$., M.C.H.C. $29.0 \%$. The film showed that practically all the cells were target cells (Fig. 2), with much punctate basophilia and $17 \%$ of reticulocytes. The red cell fragility was very much decreased. Haemolysis began at $0.32 \mathrm{NaCl}$ and was complete at $0.16 \mathrm{NaCl}$. The patient made a good immediate recovery, but suffered a second haemolytic crisis one month later associated with the symptoms of pulmonary infarct. A further haemolytic crisis also connected with a throat infection occurred on June 14, 1951. Since that date she has been very well. The liver and spleen were only palpable during the crises. A radiograph of the skull and long bones showed no abnormalities.

\section{Family History}

The mother comes from Naples where her family have always lived. The father is the son of a West African woman and a white male (nationality unknown). The patient has three brothers (Fig. 1) who are well and

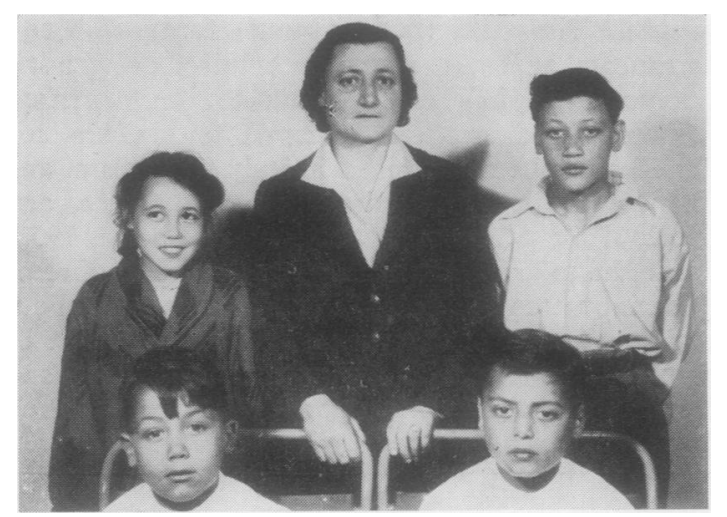

Fig. 1.-The $\mathbf{H}$ family. At back (left to right) $\mathbf{M}$. H., Mrs. H., and $\mathrm{H}$. H. In the front C. H. and L. H.

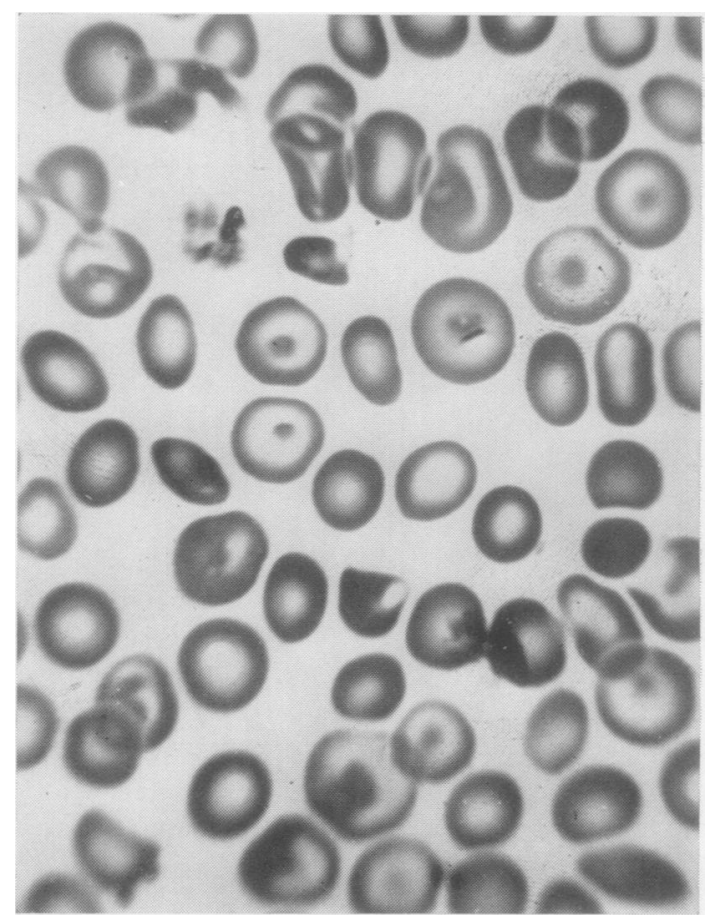

Fig. 2.-Blood film of M. H. to show target cells. $\times 1050$.

without anaemia. Preliminary estimations were per $\frac{\widehat{O}}{3}$ formed upon the blood of the family, namely, haemo globin estimation, red cell count, examination of stained़्. films, Price-Jones curves (Humble and Belyavin, 1948) osmotic saline fragility, teticulocyte count, and tests for sickling, in particular the $2 \%$ sodium metabisulphite test (Daland and Castle, 1948). In addition, the blooe. of the mother's mother, and of the mother's brothee were kindly examined for us in Naples by Dr. Maureaß who has given us permission to include his results. Iro order to exclude any irregularity in the family their blood groups were examined in the ABO, M, N, S, P, CDE/cde Kell, Lewis, and Duffy group systems by Dr. Mourane. of the Lister Institute, who has been good enough tof allow us to reproduce his results in this paper These preliminary results are summarized in Tables 1 and 20 and Figs. 3 and 4 . They suggest that Mr. H. is a sickle $\underset{W}{N}$ trait carrier, Mrs. H. is a mild case of Mediterranearo anaemia, H. H. and L. H. (brothers) are sickle-trai carriers and have very mild Mediterranean anaemia C. H. (brother) is normal, M. H. is a sickle-trait carriee (Fig. 5) with moderately severe Mediterranean anaemia? Mrs. M. (grandmother) a slight degree of Mediterranean

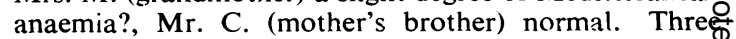
further investigations were then performed, namel@ (1) tests for foetal haemoglobin, (2) soiubility of reduce $\mathbb{B}$ haemoglobin specimens in buffers of high ionic strengths(3) electrophoresis on paper of the carboxyhaemcglobins of the family's red cells. 
TABLE I

HAEMATOLOGICAL FINDINGS IN THE “H” FAMILY

\begin{tabular}{|c|c|c|c|c|c|c|c|c|c|c|}
\hline & & & Mr. H. & Mrs. H. & Mary $\mathbf{H}$. & Hector H. & Leonard $\mathbf{H}$. & Charles H. & $\begin{array}{c}\text { Mrs. M. } \\
\text { (Grand- } \\
\text { mother) }\end{array}$ & $\underset{\text { (Maternal }}{\text { Uncle) }}$ \\
\hline $\begin{array}{l}\text { Haemoglobin }(\mathrm{g} \\
\text { Red cells }\left(10^{6} \mathrm{c}\right. \\
\text { P.C.V. } \\
\text { M.C.H. } \\
\text { M.C.H. }(\%) \\
\text { M.C.V. } \quad \cdots \\
\text { M.C.D. } \quad \cdots \\
\text { S. . } \\
\text { M.C.A.T. } \\
\text { D.T ratio } \\
\text { M.C.F. (NaCl } \\
\text { Reticulocytes } \\
\text { Sickling } \\
\text { Target cells }\end{array}$ & $\begin{array}{c}\text { ger } 10 \\
. \mathrm{mm} .) \\
\ldots \\
\ldots \\
\ldots \\
\ldots \\
\ldots \\
\text { g. } / 100 \\
\ldots \\
\ldots \\
\ldots\end{array}$ & $\begin{array}{c}00 \mathrm{ml} .) \\
\ldots \\
\ldots \\
\ldots \\
\ldots \\
\ldots \\
\ldots \\
\mathrm{mi} .) \\
\ldots \\
\ldots \\
\ldots\end{array}$ & 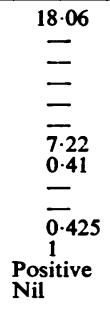 & $\begin{array}{c}13 \cdot 32 \\
5.02 \\
42 \\
26.4 \\
31 \cdot 71 \\
83.66 \\
7.36 \\
0.559 \\
1.96 \\
3.74 \\
0.385 \\
1.2 \\
\text { Negative } \\
\text { Many }\end{array}$ & $\begin{array}{c}7 \cdot 55 \\
2 \cdot 74 \\
26 \\
27 \cdot 55 \\
2903 \\
94 \cdot 89 \\
7 \cdot 73 \\
0 \cdot 686 \\
2.02 \\
3 \cdot 82 \\
0 \cdot 325 \\
17 \cdot 8 \\
\text { Positive } \\
\text { Many }\end{array}$ & 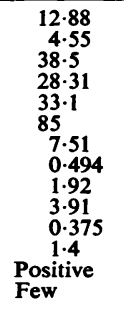 & $\begin{array}{c}13 \cdot 32 \\
5 \cdot 02 \\
38 \\
26 \cdot 4 \\
35 \\
75 \cdot 7 \\
7 \cdot 41 \\
0 \cdot 49 \\
1 \cdot 76 \\
4 \cdot 2 \\
0 \cdot 415 \\
0 \cdot 2 \\
\text { Positive } \\
\text { Occasional }\end{array}$ & $\begin{array}{c}13 \cdot 47 \\
4 \cdot 5 \\
40 \\
30 \\
33 \cdot 67 \\
88 \cdot 88 \\
7 \cdot 36 \\
0 \cdot 4 \\
2 \cdot 01 \\
3 \cdot 5 \\
0 \cdot 46 \\
0 \cdot 8 \\
\text { Negative } \\
\text { Nil }\end{array}$ & 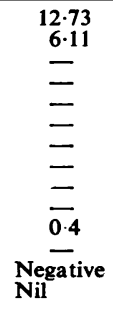 & 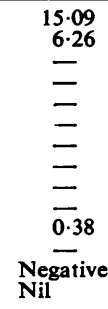 \\
\hline
\end{tabular}

TABLE II

BLOOD GROUPS OF THE “ $H$ " FAMILY

\begin{tabular}{|c|c|c|c|c|c|c|c|c|c|}
\hline Name & ABO & $\mathbf{R h}$ & $\mathbf{M N}$ & $\mathbf{S}$ & $\mathbf{P}$ & $\mathrm{Fy}_{\mathbf{a}}$ & Lea & Leb & Kell \\
\hline $\begin{array}{ll}\text { Mr H. H. } & \ldots \\
\text { Mrs. H. } & \ldots \\
\text { M. H. } & \text { H. } \\
\text { H. H. } & \ldots \\
\text { L. H. } & \text { H. } \\
\text { C. H. } & \ldots\end{array}$ & $\begin{array}{l}\mathbf{O} \\
\mathbf{B} \\
\mathbf{B} \\
\mathbf{O} \\
\mathbf{O} \\
\mathbf{O}\end{array}$ & $\begin{array}{l}\text { rr cde.cde } \\
R_{1} \text { r CDe.cde } \\
\text { Ir cde.cde } \\
\text { Ir cde.cde } \\
\text { Ir cde.cde } \\
\text { rr cde.cde }\end{array}$ & $\begin{array}{l}\mathbf{M} \\
\mathbf{M} \\
\mathbf{M} \\
\mathbf{M} \\
\mathbf{M} \\
\mathbf{M}\end{array}$ & $\begin{array}{l}\overline{+} \\
+ \\
\overline{+} \\
-\end{array}$ & $\begin{array}{c}+\stackrel{+}{+}+ \\
\dot{+} \\
++ \\
+++\end{array}$ & $\begin{array}{l}\bar{t} \\
\overline{-} \\
- \\
-\end{array}$ & $\begin{array}{l}- \\
\overline{-} \\
\overline{-} \\
-\end{array}$ & $\begin{array}{l}- \\
- \\
- \\
-\end{array}$ & $\begin{array}{l}- \\
- \\
- \\
-\end{array}$ \\
\hline
\end{tabular}
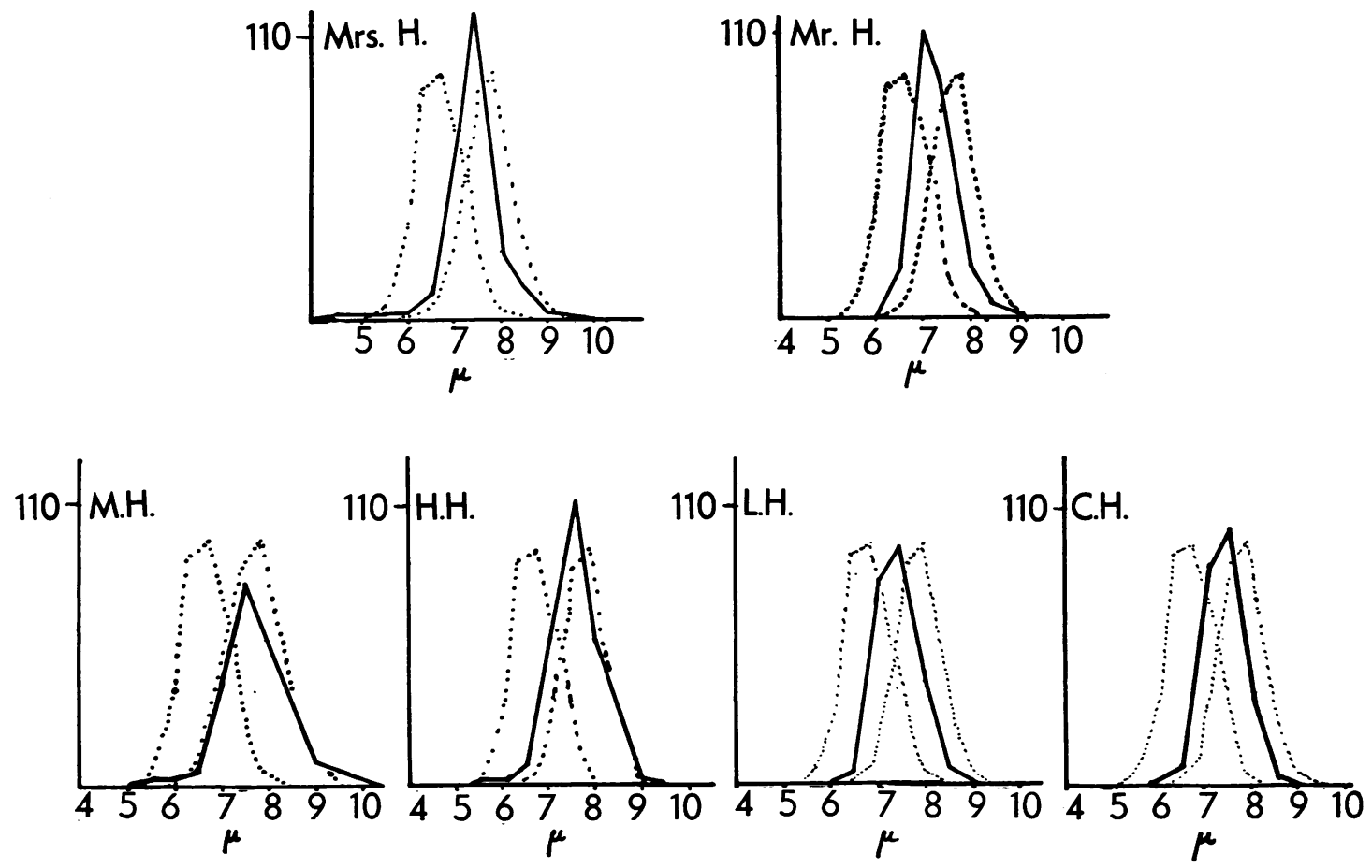

F1G. 3. -The Price-Jones curves of the $\mathbf{H}$ family, to show the " broad-based" curves of Mrs. H., M. H., H. H., and L. H. 

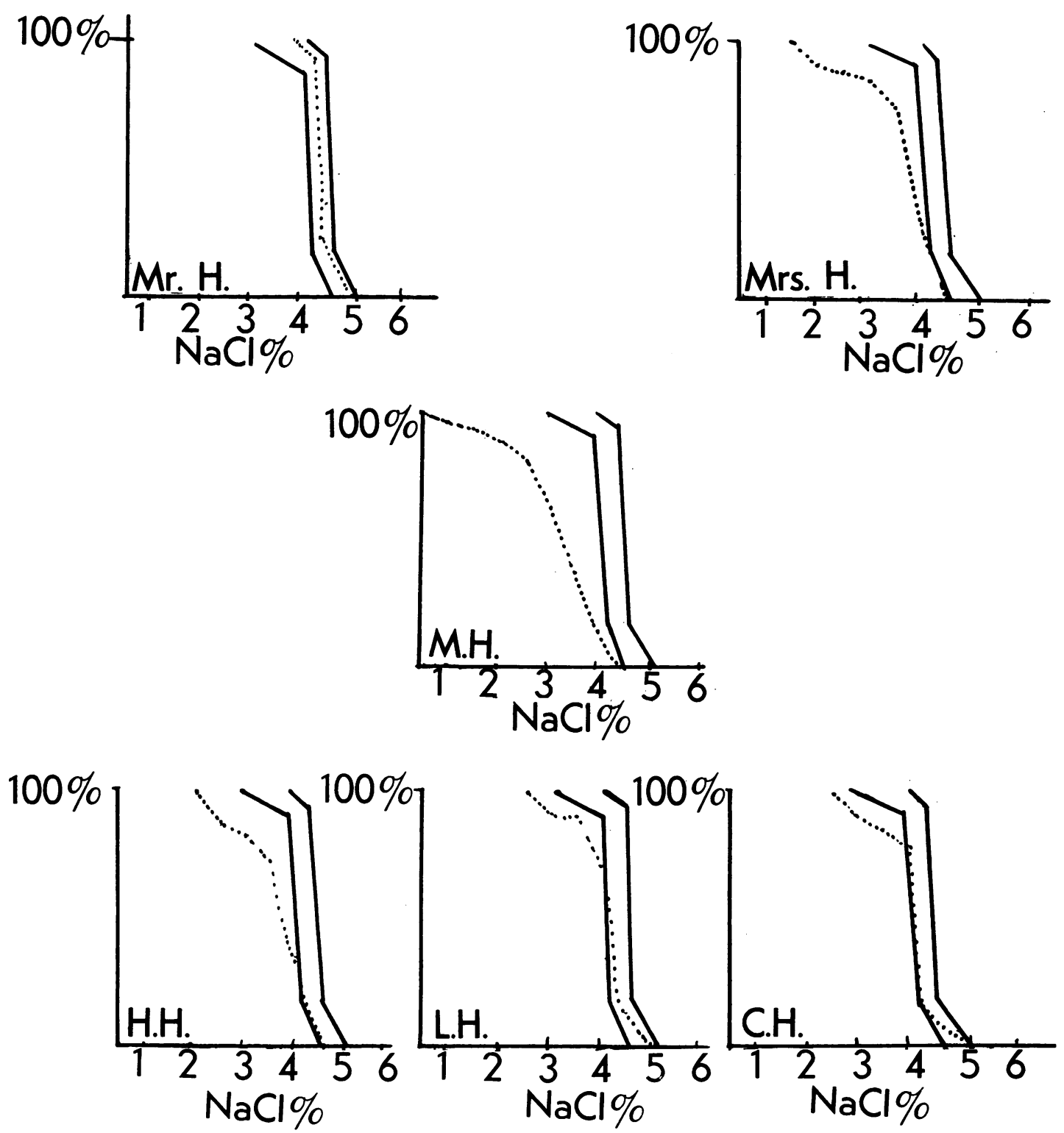

FIG. 4.-The saline fragilities of the $H$ family to show the decreased fragilities_of Mrs. H., M. H., H. H., and L.'H.

Test for Foetal Haemoglobin.- No foetal haemoglobin could be detected in any member of the $\mathbf{H}$. family using the method of alkali denaturation and two ultra-violet spectrophotometric methods (Beaven and White, 1953). These tests were carried out by one of us (J. C. W.) as part of a series to be reported elsewhere in cooperation with the M.R.C. Spectrographic Unit, London Hospital, with Drs. G. H. Beaven and E. A. Johnson.

Determination of Solubility of Reduced Haemoglobin in Phosphate Buffer pH 6.7 of High Ionic Strength.Solubilities of reduced haemoglobin samples were determined by salting-out in $p \mathrm{H} 6.7$ phosphate buffer at four high ionic strengths, $\mathrm{r} / 2,3.84,4.31,4.75$, and 5.45 . In this range, both normal and sickle-cell haemoglobıns $\infty$ obey the linear Cohn relationship between log solubility and ionic strength (Cohn and Edsall, 1943; Jope and O'Brien, 1949; Perutz and Mitchison, 1950; Perutz, Liquori, and Eirich, 1951).

The tests were set up in $12 \times 100 \mathrm{~mm}$. pyrex tubes with $\stackrel{\overrightarrow{\mathrm{D}}}{\stackrel{\mathrm{Q}}{2}}$ the requisite amounts of stcck $3.2 \mathrm{M}$ buffer of $p \mathrm{H} 6.7$ (Green, 1933) and water, concentrated destromaiized haemoglobin solution from laked erythrocytes, and응 


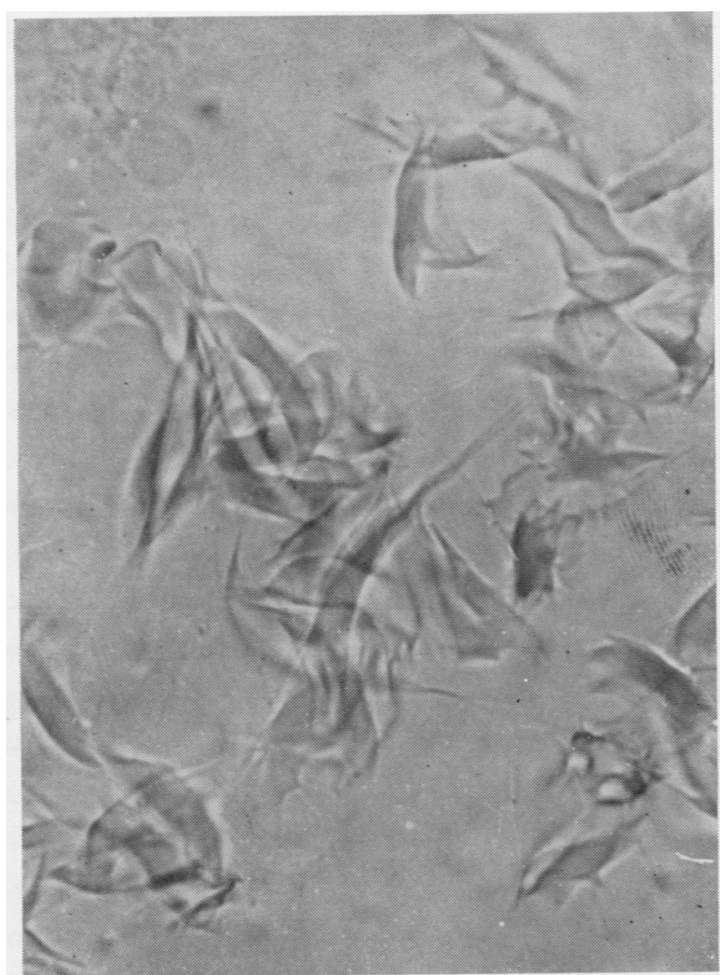

Fig. 5.- " Moist stasis" preparation of the blood of M. H. to show sickle cells. $\times 1050$.

reducing agent to a total volume of $5 \mathrm{ml}$. The reducing agent was $0.1 \mathrm{ml}$. of freshly prepared $\mathrm{M} / 2$ ferrous citrate (Jope and O'Brien, 1949). The setting up was performed with a stream of nitrogen playing over the tube contents, and after sealing with a rubber stopper and a coating of paraffin wax-vaseline compound, equilibration was carried out fcr five days at $22^{\circ} \mathrm{C}$., with gentle mixing on each of the first three days. The tubes were opened in the presence of nitrogen and the clear liquid phase pipetted off, or if necessary, centrifuged first under liquid paraffin. The solution was then treated with carbon monoxide, and the carboxyhaemoglobin estimated in the photoelectric colorimeter against the Haldane standard, $100 \%-14.8 \mathrm{~g} . / 100 \mathrm{ml}$.

The results are expressed in Fig. 6, where the heavy line 1 is drawn through the mean points at the ionic strength for the solubility of reduced haemoglobin of 13 individuals with normal blood or with various nonsickling anaemias. Line 3 similarly represents the mean solubility of four sickle-cell anaemia haemoglobin samples, and line 2 the mean solubility of 11 sickle-cell trait samples. The results on the haemoglobins of the family show that the son, C. H., possesses haemoglobin of normal solubility and that the haemoglobins of the father, the sons H. H. and L. H., and the patient M. H. possess solubilities comparable with those found in other sickle-trait carriers. It will be seen that then the solubility of the mother's haemoglobin is on the low side of normal; a trace of sickle haemoglobin cannot be excluded unequivocally by this method.

Electrophoresis on Paper of Carbon Monoxide Haemoglobins.-Samples of blood were collected in oxalate; the red cells were washed five times in normal saline, the final suspension of cells in saline was left overnight at $3^{\circ} \mathrm{C}$. in an atmosphere of carbon monoxide. Finally, the saline was replaced by distilled water saturated with carbon monoxide and stored at $-5^{\circ} \mathrm{C}$. After storage the haemoglobin content of the samples was adjusted to 3 g. $\%$, centrifuged at 6,000 r.p.m. for an hour; to the supernatant was added $0.5 \mathrm{~g} . \%$ of pure albumin; this mixture was used for electrophoresis. (Albumin bas a much higher mobility than haemoglobin, and serves to increase the separation of the haemoglobins.)

Electrophoresis.-Carboxyhaemoglobin, $20 \mathrm{mg}$., was put on Whatman No. 1 filter paper and placed in a modified partition box (Flynn and de Mayo, 1951). Carbon monoxide was passed through the box for three nours followed by nitrogen (oxygen free); then while

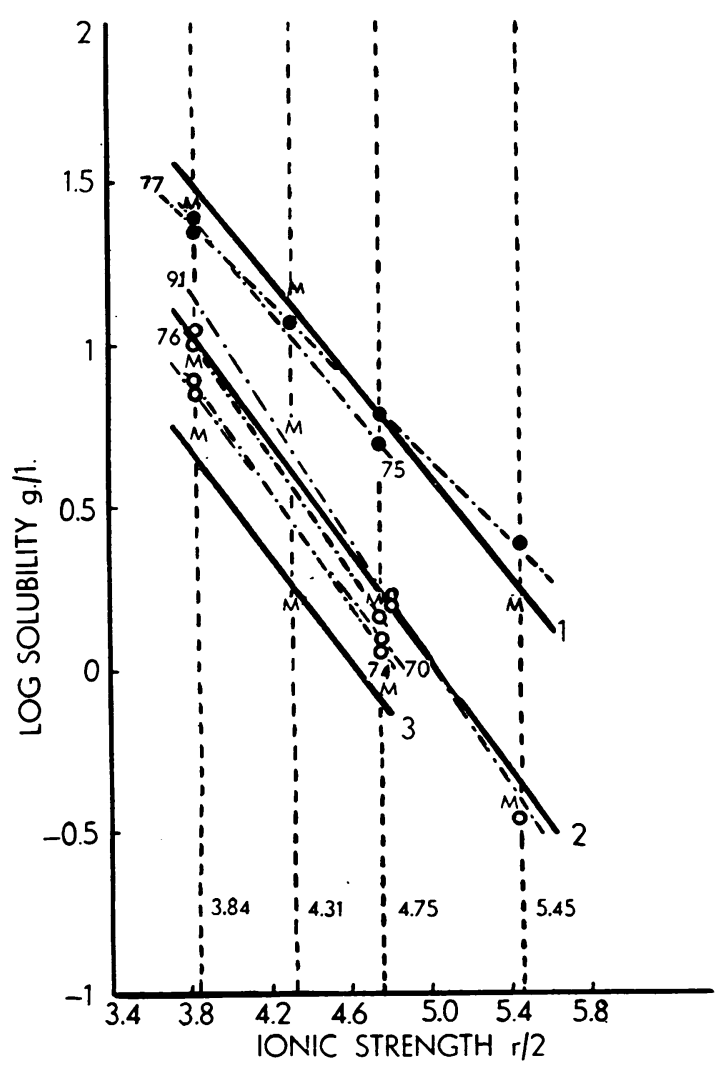

FIG. 6.-Solubility of reduced haemoglobin in $p H 6.7$ phosphate buffer at various ionic strengths. Line 1 . Mean solubility of 13 normal haemoglobins. Line 2. Ditto for 11 sickle cell trait haemoglobin specimens. Line 3. Ditto for four sickle cell anaemia haemoglobin specimens. 91 is Mr. H., 75 is Mrs. ${ }_{-} \mathrm{H}$., 70 is M. H., 74 is H. H., 76 is L. H., 77 is C. H. 

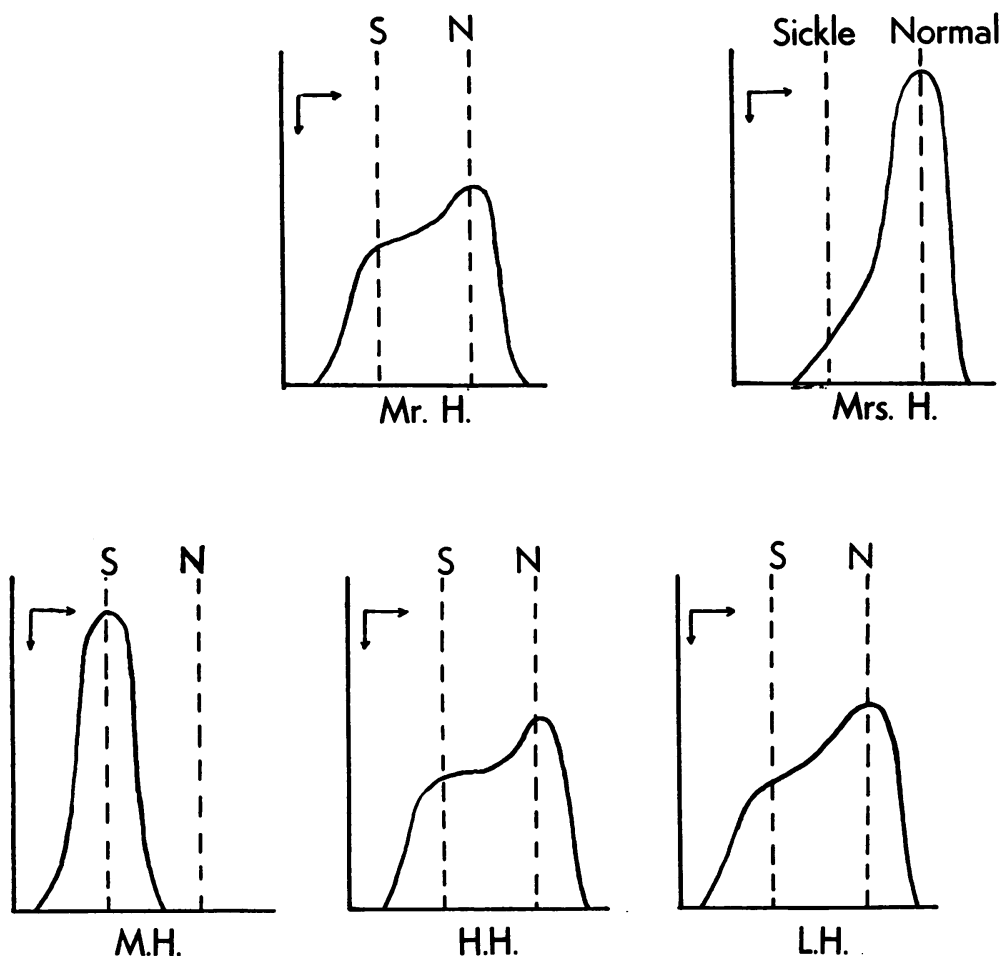

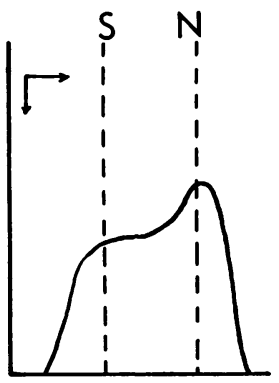

H.H.

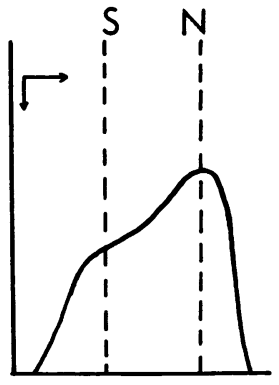

L.H.

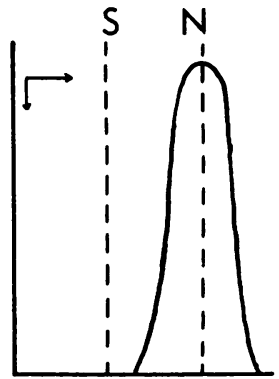

C.H.

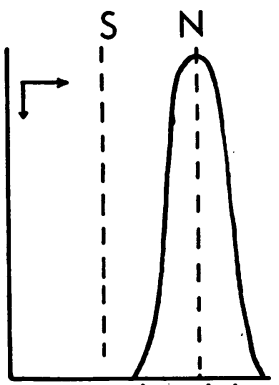

Normal Adult

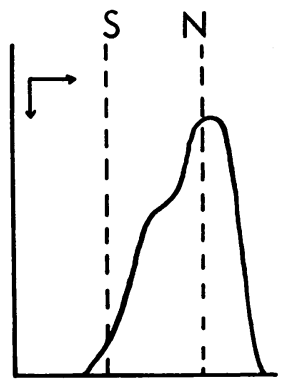

Foetal

FIG. 7. - The electrophoretograms of haemoglobin samples from the $\mathbf{H}$ family together with a normal specimen and a specimen of cord blood. Paper-electrophoresis, buffer pH 8.6

the nitrogen flow continued the troughs were filled with barbiturate buffer at $\mathbf{p H}$ 8.5. Finally, when the paper was saturated with buffer, a current of $350 \mathrm{v} .1 .0 \mathrm{ma} / \mathrm{cm}$. width was applied and allowed to run for 48 hours. The whole procedure, after the application of the haemoglobin solutions, being carried out with the exclusion of light to prevent a shift to the right in the reaction $\mathrm{CO} \mathrm{Hb} \rightleftharpoons \mathrm{CO}+\mathrm{HbO}_{2}$.

Estimations were made, after staining with a purified naphthalene black, with a mechanical scanner automatically recording on light-sensitive paper, using a scale calibrated by known quantities of haemoglobin solution (Crook, Harris, and Warren, 1952). The photo recordings were plotted on a linear scale; the area under each peak then corresponds to the amount of protein present.

Results.-Fig. 7 shows the electrophoretic pattern of normal adult and foetal carboxyhaemoglobin compared with the patterns of the $\mathbf{H}$. family. It will be seen that at $p H 8.5$ normal haemoglobin moves faster than foetal or sickle haemoglobin. Mr. H. shows a mixture of sickle and normal haemoglobin; Mrs. H. shows a majority of normal haemoglobin, but there is some tailing 


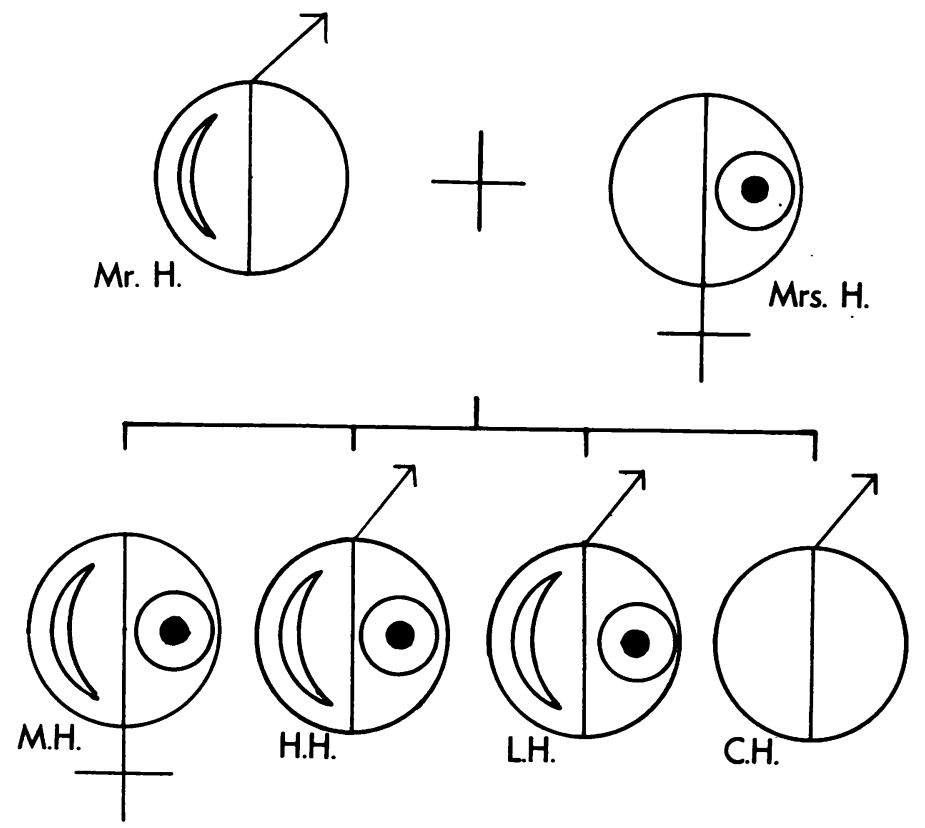

FIG. 8.-The inheritance of sickle trait and Mediterranean anaemia in the $H$ family. $\Theta=$ sickle trait. $\odot=$ Mediterranean trait.

on the paper. Of the children, M. H. shows a predominance of sickle haemoglobin by this technique; H. H. and L. H. show a mixture of sickle and normal haemoglobin, and C. H. shows entirely normal haemoglobin.

Further electrophoretic experiments were made by adding the dialysed fractions obtained in the solubility experiments to known normal haemoglobin. It was found that $4.5 \%$ of sickle haemoglobin could not be detected in the presence of $95.5 \%$ adult haemoglobin. Conversely, $4.5 \%$ of normal naemoglobin could not be detected in the presence of $95.5 \%$ sickle haemoglobin. It is thus impossible to categorize with certainty the trace of ? abnormal haemoglobin seen in the electrophoretogram of Mrs. H. or the trace of ? normal haemoglobin in that of $\mathbf{M}$. $\mathbf{H}$.

These special methods confirmed the opinion produced by the conventional examinations that there were two conditions present in this family. The inheritance of the two conditions is set out in Fig. 8.

\section{Discussion}

Clinically these cases are of great interest, and two differing syndromes are often mistaken for the haemolytic crises which so frequently occur. As they suffer from fever, pain in the bones, and a loud heart murmur, a diagnosis of rheumatic fever is frequently made. Our patient was so diagnosed at the age of 6 . The second common syndrome is an attack of pulmonary thrombosis causing an infarct, again a feature of our patient's history. It will be noted that the patient $\mathrm{M}$. $\mathrm{H}$. is anaemic and has a much more abnormal fragility curve, and an abnormally flattened Price-Jones curve compared with her two affected brothers. These results suggest that if the sickle trait is associated with an inheritance of Mediterranean anaemia, then the two conditions augment each other and produce clinical symptoms (Silverstroni and Bianco, 1952). It will be seen that the patient M. H. has much more sickle haemoglobin than her brothers (Fig. 7). This factor also would tend to make symptoms more likely. Although the mother's haemoglobin is predominantly of the normal and adult form, the examination does not completely preclude the co-existence of a small percentage of sickle haemoglobin. This rare possibility has been described by Singer and Fisher (1953), but the numerous target cells, slight hypochromia, and increased resistance to saline haemolysis of the red cells are consistent with the occurrence of Mediterranean trait in this southern Italian woman (Wintrobe, Matthews, Pollack, and Dobyns, 1940). It appears that the double inheritance of the sickle cell Mediterranean anaemia is responsible for many of the cases reported in the literature of sickle cell anaemia occurring in white races. The association of sickling with the Negro races has produced in this connexion many circuitous and unnecessary explanations, for it is clear from the study of this family that the sickle-trait may lie concealed beneath the Caucasian features.

\section{Summary and Conclusions}

A family exhibiting the double inheritance of the sickle-trait and Mediterranean anaemia is described.

The family was discovered by the coincidental illness of one of its members.

The presence of sickle-cell haemoglobin was demonstrated in the blood of the father, of the affected daughter, and of two of the sons by determining the solubility of the haemoglobin in the reduced state.

Sickle-cell haemoglobin was also demonstrated in the blood of these four members of the family by the technique of paper electrophoresis, but not in the blood of the mother or of the third son.

Attention is drawn to the additive effect of the two conditions in the production of clinical disease. 
The authors wish to acknowledge with gratitude the assistance given by Dr. Mourant in determining the blood groups of the family and to Dr. Maurea for examining the blood of Mrs. M. and Mr. C. Our thanks are also due to Dr. Peter Hansell, of the Department of Medical Photography, Westminster Medical School, for his assistance with the illustrations.

\section{REFERENCES}

Beaven, G. H., and White, J. C. (1953). Nature, Lond., 172, 1006. Caminopetros, J. (1952) Lancet, 1, 687

Cohn, E. J., and Edsall, J. T. (1943). Protein, Amino Acids, and Peptides as Ions and Dipolar Ions. $\begin{gathered}\text { Protein, Amino Acids } \\ \text { Reinhold, New York. }\end{gathered}$

Crook, E. M., Harris, H., and Warren, F. L. (1952). Biochem. J., 51, xxvi.

Daland, G. A., and Castle, W. B. (1948). J. Lab. clin. Med., 33, 1082.

Flynn, F. V., and Mayo, P. de (1951). Lancet, 2, 235.

Green, A. A. (1933). J. Amer. chem. Soc., 55, 2331.
Humble, J. G., and Belyavin, G. (1948). Journal of Clinical Pathology,

1, 77.
Itano, H. A. (1951). Proc. Wash. nat. Acad. Sci., 37, 775.

Itano, H. A. (1951), Proc. Wash. nat. Acad. Sci., 37, 775.
Jope, H. M., and O'Brien, J. R. P. (1949). Haemoglobin; Barcroft Memorial Volume, ed. F. J. W. Roughton and J. C. Kendrew, p. 269. Butterworth, London.

Kaplan, E., Zuelzer, W. W., and Neel, J. V. (1951). Blood, 6, 1240

Liquori, A. M. (1951). Nature, Lond., 167, 950.

National Institutes of Health. Hematology Study Section (1953). Blood, 8, 386 .

Blood, 8, 386.
Neel, J. V., Itano, H. A., and Lawrence, J. S. (1953). Blood, 8, 434.

Neel, J. V., Itano, H. A., and Lawrence, J. S. (1953), Blood, 8, 434.
Pauling. L., Itano, H. A., Singer, S. J., and Wells, I. C. (1949). Science, 110, 543 .

Perutz, M. F., and Mitchison, J. M. (1950). Nature, Lond., 166, 677. - Liquori, A. M., and Eirich, F. (195i). Ibid., 167, 929.

Powell, W. N., Rodarte, J. G., and Neel, J. V. (1950). Blood, 5, 887.

Silvestroni, R., and Bianco, I. (1952). Ibid., 7, 429.

Singer, K., Chernoff, A. I., and Singer, L. (1951a). Ibid., 6, 413.

- (195ib). Ibid., 6, 429.

and Fisher, B. (1953). Ibid., 8, 270.

Sturgeon, P., Itano, H. A., and Valentine, W. N. (1952). Ibid., 7, 350.

Wells, I. C., and Itano, H. A. (1951), J. biol. Chem., 188, 65 .

Wintrobe, M. M., Matthews, E., Pollack, R., and Dobyns, B. M. (1940). J. Amer. med. Ass., 114, 1530. 